\title{
Semiotic analysis of the poetry "Morgenlied" by Martin Opitz
}

\author{
Prilimercy E. Kojongian ${ }^{*}$
}

German Language Education Study Program, Department of Foreign Language Education, Faculty of Language and Art, Manado State University, Indonesia

\begin{tabular}{l}
\hline Article Info \\
\hline Article history: \\
Received Aug $25^{\text {th }}, 2021$ \\
Revised Sept $16^{\text {th }}, 2021$ \\
Accepted Oct $12^{\text {th }}, 2021$ \\
\hline
\end{tabular}

\section{Keyword:}

Semiotic analysis

Morgenlied

Martin Opitz

\begin{abstract}
A This study aims to examine the sign system in the form of icons, indexes, and symbols and to interpret the meanings and messages as well as moralreligious values contained in the poem "Morgenlied" by Martin Opitz. The method used is a content analysis method with a qualitative approach based on semiotic analysis. This method serves to examine the poem "Morgenlied" by Martin Opitz, especially on the sign system in the form of icons, indexes, and symbols as well as religious moral values contained in the poem. While the data collection technique is a literature study. Based on the semiotic analysis, this poem contains a religious element in the form of a prayer of thanksgiving to God for His mercy and glory.
\end{abstract}

(C) 2021The Authors. Published by IICET.

This is an open access article under the CC BY-NC-SA license

(https://creativecommons.org/licenses/by-nc-sa/4.0)

\section{Corresponding Author:}

Prilimercy E. Kojongian,

Manado State University

Email: prilimercykojongian@unima.ac.id

\section{Introduction}

Literary works are a place to express a picture of human life itself and document something, be it an event or an expression of feeling expression, which is then used as a means of communication between the author and the reader. In connection with that (Sumardjo and Saini, 1988) in Rokhmansyah (2014: 2) says that "literary work is a person's expression in the form of experiences, thoughts, feelings, ideas that are described concretely by using language as a tool." Rokhmansyah (2014: 2) also says that literary works are written with full appreciation and a touch of the soul that is packaged in a deep imagination about life.

As a student of the German Language Study Program, during the study period, apart from studying German language skills, he also studied German literature. This can be seen in the course "Ausgewählte literarische Werke", researchers are taught to interpret German poetry. At the time of interpreting these poems, the researcher gained a unique and interesting experience. When reading and understanding poetry, a person will not only feel entertained by the diction in the poem but also gain a lot of knowledge in the form of moral messages, religious values, even events that occur in a country, place, or person, and most importantly the reader can understand the message written by the author. author.

Based on the experience of interpreting German poetry, the idea arose to research Martin Opitz's poem "Morgenlied". Because the content of this poem is very interesting. This poem was born in the Baroque era, written in Leipzig in 1634. This poem tells a lot about the gratitude and hope and prayer of the German people to God Almighty, because of the many foreign war soldiers who entered and spread in Germany. Therefore, this poem contains religious or religious elements. 
Martin Opitz is one of the most influential German writers and baroque poets in Germany. He is also one of the founders of the Silesian School of Poetry. He was born in Bunzlau, December 23, 1597, and died on August 20, 1639, in Gdansk. As a writer, Martin Opitz has written many poems that tell about events in the Baroque era. Where at this time some many foreign troops and fugitives came to Germany, thus affecting the German language and causing the German language both spoken and written to be mixed with other languages, especially Romance.

To understand and capture the meaning behind the words and the elements that make up poetry, as well as the things behind the formation of a poem, an in-depth study is needed. So that the meaning and message contained in the poem can be channeled properly and give a positive impact for every reader. The focus of the study can be studied using a semiotic approach.

The semiotic approach in the study of literature is based on semiotic theory. The semiotic approach serves to reveal all the meanings behind the signs in poetry or the text of poetry. Semiotics can not only study texts in linguistics or language, but can also be related to other things, such as words are signs, as well as gestures, traffic lights, flags, structures in literature, and everything that can be observed and interpreted is signed in human life.

The main figures of semiotics, namely Ferdinand de Saussure (1857-1913), a linguist, and Charles Sander Pierce (1839-1914), a philosopher and logician. According to Pierce in Basalamah (2008: 24-25) reasoning is done through signs, humans can only think through signs. That is why he puts logic as the basis of semiotics and calls semiotics a synonym for logic and argues that semiotics can be applied to all kinds of signs. Meanwhile, according to Saussure, language is the most complete science of signs, so that it can be used as the subject of study. Therefore, Saussure started the science of signs by giving theoretical foundations to the science of linguistics (linguistics).

Based on the description described above, the researcher is interested in taking study material from one of the German poems by Martin Opitz using a semiotic approach. This research is entitled: Semiotic Analysis of the Poetry "Morgenlied" by Martin Opitz.

\section{Method}

This research is literary research that uses a qualitative approach with semiotic analysis in a poem. This study only displays the results of the data without any manipulation or other treatment. This method also tends to analyze the data inductively. Therefore, researchers collect data or evidence not to prove hypotheses, but to develop theories based on specific things that can be found and collected. Then the results of the data are presented and concluded.

The method used is the method of content analysis. According to Krippendorff (1990) in Lendo (2015: 22 $23)$, the term content analysis with qualitative content analysis is a method for analyzing or interpreting texts and paying attention to the context. The function of this method is to analyze or interpret discourse, text, and images. In this regard, this study uses a semiotic-based content analysis method, namely research that examines how poets use or add semiotic signs in their poetry. This study will examine the signs, meanings, and religious values contained in the poem Morgenlied by Martin Opitz.

About the method used in analyzing the data, there are several collection procedures based on the procedures proposed by According to Hikmat et al (2017:103-107) and semiotic-based data analysis in this study, namely: 1) The researcher chooses one of the German poems to be studied; 2) The researcher determines the approach that will be used to analyze the poetry that has been previously selected; 3) The researcher raised the theme of semiotic analysis in one of the German poems, entitled Morgenlied by Martin Opitz based on the theory of Charles Sander Pierce; 4) Researchers read Morgenlied's poetry repeatedly, to understand and find signs contained in Morgenlied's poetry; 5) Researchers conduct semiotic analysis, to find and examine signs (in the form of icons, indexes, and symbols), religious meanings, and values contained in Morgenlied poetry; 6) The researcher interprets Morgenlied poetry based on the signs (icon, index, and symbol) contained in Morgenlied poetry; 7) Researchers describe conclusions and suggestions after finding research results.

The main data in this study is the poem Morgenlied by Martin Opitz, which was taken in the bilingual poetry anthology book Blauer Abend in Berlin, written by Berthold Damshäuser and Ramadhan KH, published in 1989. Meanwhile, other data related to this research was taken from several book sources and the internet. 


\section{Results and Discussions}

\section{Semiotic Analysis of Poetry}

\section{Heuristic reading}

Heuristic reading is one of the instruments in understanding something in a literary work and reading the first level of literary works in the semiotic system (Nurgiyantoro, 2007: 33). This reading is done to obtain a correct understanding and clarify grammatically ambiguous language. This is due to deviations from grammatical rules that often occur in a language in poetry. The contents of the complete poem are as follows:

\section{Morgenlied}

O Licht, geboren aus dem Lichte,

O Sonne der Gerechtigkeit,

Du schickst uns wieder zu Gesichte

Die angenehme Morgenzeit.

Drum will uns gehören,

Dankbarlich zu ehren

Solche deine Gunst;

Gib auch unsern Sinnen,

Daß sie sehen können

Deiner Liebe Brunst.

Laß deines Geistes Morgenröte In unsern tunkeln Herzen sein,

Daß sie mit ihren Strahlen töle Der eitlen Werke kalten Schein.

Siehe, Herr, wir wanken,

Tun und auch Gedanken

Gehn auffalscher Bahn.

Du wollst unserm Leben

Deine Sonne geben,

Daß es wandeln kann.

Verknüpfe mit des Friedens Bande

Der armen Kirchen schwache Schar,

Nimm weg von unserm Vaterlande

Verfolgung, Trübsal und Gefahr.

Laß uns ruhig bleiben,

Unsern Lauf zu treiben

Diese kleine Zeit,

Bis du uns wirst bringen,

Wo man dir soll singen

Lob in Ewigkeit.

The translation in Indonesian is as follows:

\section{Morning Depending}

O light, born of light,

O sun of justice

You send it back to our face

Nice morning time.

We deserve it

Sincerely and thank you

At Your grace;

Strengthen our senses

So that you can see

The passion of my love.

Enter the twilight of your spirit

Into our dark souls,

To turn it off with its rays

The cold glint works in vain. 
Behold, Lord, we hesitate,

Actions and thoughts

Moving on the wrong track.

Hope in our life

You gave your sun,

So that it changes.

Tie with the rope of peace

Weak congregations,

Remove from our homeland

Persecution, depression, and danger.

Give us peace

To go through the journey

This short time,

Until you will take us,

To where we will sing

Blessed are you forever.

In general, this Morgenlied poem uses good German and its meaning can be understood grammatically. However, there are some sentences that the author deliberately changes the grammatical form and arrangement of, which aims to create a rhyme at the end of the line, so that in the poem an aesthetic effect arises. For example, in the sentence, Da $\beta$ sie mit ihren Strahlen the (stanza -2, line -3), the sentence should be in the form of $\mathrm{Da} \beta$ sie mit ihren Strahlen tötet, where the word the should be conjugated according to the subject of sie, namely tötet, but this is done by the poet to cause the same rhyme as the end of line-1 in stanza2 , thus forming a cross rhyme $(a, b, a, b)$. Some have changed the sentence structure, for example, Wo man dir soll singen (verse-3, array-9), grammatically it should be in the form of Wo man dir singen soll (relative sentence, modal verb). Where should the conjugated verb, the modal verb, or the modal verb, be at the end of the sentence. However, this was deliberately changed to highlight the same rhyme at the end of lines-5, -6 , and -8 , thus forming the rhyme $a a, b, a a, b$. Based on this, it seems clear that the author deliberately ignored the grammatical rules that should be obeyed, but this is justified in poetry.

\section{Hermeneutic Reading}

Hermeneutic reading is the second stage of semiotic analysis. According to Teeuw (1984) in Nurgiyantoro (2007:33), hermeneutics is a science or technique to understand literary works and their language expressions in a broad sense. This hermeneutic reading is done by understanding the whole based on the elements and understanding the elements based on the whole. In this regard, this study deals with the sign system in Morgenlied poetry, namely icons, indexes, and symbols.

Tabel 1 . The Sign System in Morgenlied Poetry

\begin{tabular}{ccc}
\hline Dixie / Frasca & Verse / Array & Sign \\
\hline Lichte & $1 / 1$ & Indeks \\
Sonne der Gerechtigkeit & $1 / 2$ & Symbol \\
Sinnen & $1 / 8$ & Icon \\
Brunst & $1 / 10$ & Indeks \\
Morgenröte & $2 / 1$ & Indeks \\
tunkeln Herzen & $2 / 2$ & Symbol \\
Sonne & $2 / 9$ & Indeks \\
Bande & $3 / 1$ & Symbol \\
Vaterlande & $3 / 3$ & Icon \\
Ruhig & $3 / 5$ & Indeks \\
kleine Zeit & $3 / 7$ & Symbol \\
Ewigkeit & $3 / 9$ & Icon \\
\hline
\end{tabular}

The first stanza in Lichte's diction in this poem has the meaning of "light", which is a sign in the form of an index, which refers to God, which implies existential closeness. Likewise with the phrase Sonne der Gerechtigkeit which means "sun of justice". Phrases are signs in the form of symbols that have a conventional relationship from the depiction of God's power and glory. Likewise, in Sinnen's diction, it means "senses" which are iconic signs that have similarities to the depiction of faith, belief, and the human mind itself. Then Brunst's diction which according to the dictionary means "a period of lust or lust" is a sign in the form of an in 
existence that has a close existence with a description of the greatness of love or God's love which is supported by the previous diction, namely Liebe which means "love or love".

The second stanza in Morgenröte's diction which means "dawn" is a sign in the form of an index, which has an existential closeness to its description as the light of truth. In Herzen's tunnel phrase which means "dark soul or heart" is a sign in the form of a symbol, which has a conventional relationship from the depiction of a bad side of human nature. Then in Sonne's diction, "the sun" is a sign in the form of an index, which has an existential closeness that is described by the author as light or the right path for humans.

Furthermore, stanza 3 in Bande's diction which means "rope" is a sign in the form of a symbol, which is described as an attempt or connection to unite or repair something that is broken or damaged. Vaterlande's diction means "homeland" is a sign in the form of an icon, which has similarities to situations or life in humans. In the ruhig diction which means "calm, quiet, lonely or silent" is a sign in the form of an index and has an existential relationship, this is described by the author as tranquility or peace. Then in the diction, Kleine Zeit which means "short time" is a sign in the form of symbols containing conventional elements described as a short life. Whereas in Ewigkeit's diction which means "eternity or eternity" is a sign in the form of an icon that has a similar meaning to heaven.

Overall, this poem contains three sign systems, namely icons, indexes, and symbols, although indexes and symbols are more dominant than icons. This is because the poet describes the relationship between the sign referred to as a causal or causal relationship (index) and the relationship with things that are conventional or agreement (symbols), rather than relationships that are similar in form (icon).

\section{The Religious Values of Poetry}

Religious moral values taken in literary works are not to use violence, to help each other, not to force the will or not to be selfish, to uphold honesty, to live and practice the teachings of one's religion correctly, and to rely on God in all things. There are also religious moral values in this poem, starting with the title of the poem Morgenlied, the meaning of this title is "Dendang Pagi or Song of the Morning", but based on the content of each diction in this poem it describes prayer to God, in which it expresses a lot of feelings. thanksgiving for the new day given and asking for help or accompaniment for the day that will run later. Based on this, it is clear that this poem contains many religious values.

\section{Bait 1 :}

O Licht, geboren aus dem Lichte,

O Sonne der Gerechtigkeit,

Du schickst uns wieder zu Gesichte

Die angenehme Morgenzeit.

Drum will uns gehören,

Dankbarlich zu ehren

Solche deine Gunst;

Gib auch unsern Sinnen,

Daß sie sehen können

Deiner Liebe Brunst.

O light, born of light,

$\mathrm{O}$ sun of justice

You sent it back to our faces in the good morning.

We deserve it

Sincerely and thank you

At Your grace;

Strengthen our senses

So that you can see

Your love.

In lines 1 and 2, the author describes God and His power, which is described in Lichte's diction and the phrase Sonne der Gerechtigkeit. Then lines 3 and 4 are a continuation of lines 1 and 2, which reveal that God has sent back His power to each of His people as described in Geschichte's diction. There is also a phrase that reads Die angenehme Morgenzeit is an expression of gratitude to God for the beautiful new day that He has given. Then this thanksgiving is clarified again with the next line of Drum will uns gehören, Dankbarlich $\mathrm{Zu}$ Ehren which expresses that we must be grateful for God's grace. Then in lines 7-10 the author wants to reveal how the goodness and greatness of God's love for His people, which humans want to feel. This is clarified in 
Sinnen's diction which describes the self or human faith and Deine Liebe Brunst, where this Deine refers to God and Liebe Brunst expresses the greatness of God's Love that humans want to feel or see, which is clarified in the line $\mathrm{Da} \beta$ sie sehen können. Overall in verse 1, the author would like to express gratitude to God for His mercy, goodness, and great love for every human being.

\section{Bait 2 :}

Laß deines Geistes Morgenröte In unsern tunkeln Herzen sein, Daß sie mit ihren Strahlen töle Der eitlen Werke Kalten Schein.

Siehe, Herr, wir wanken,

Tun un auch Gedanken

Gehn auffalscher Bahn.

Du wollst unserm Leben

Deine Sonne geben,

Daß es wandeln kann.

Enter the twilight of your spirit

Into our dark souls,

To turn it off with its rays

The cold glint works in vain.

Behold, Lord, we hesitate,

Actions and thoughts

Moving on the wrong track.

Hope in our life

You gave your sun,

So that it changes.

In this verse, the author wants to reveal how humans ask God for help to get rid of the dark side in humans and useless actions or treatments or temporary worldly desires, which are expressed in the lines In unseen Dunkeln Herzen sein and Der little Werke kalten Schein, with God's intervention through His power and the light of truth, which is believed to be able to get rid of this darkness, is stated in lines 1 and 3.

Then in line 5, it is explained that humans begin to feel doubtful and shaky "Siehe, Herr, wir wanken" about human actions and thoughts that are on the wrong or deviant path or path. So that in lines 8-10 the author pours out human feelings that want to be changed by hoping for help from God, which is described in Sonne's diction. Based on this, in this verse, the author wants to reveal how weak humans are without the intervention of God and humans themselves who want to return to the right path.

\section{Bait 3 :}

Verknüpfe mit des Friedens Bande

Der armen Kirchen schwache Schar,

Nimm weg von unserm Vaterlande

Verfolgung, Trübsal und Gefahr.

Laß uns ruhig bleiben,

Unsern Lauf zu treiben

Diese kleine Zeit,

Bis du uns wirst bringen,

Wo man dir soll singen

Lob in Ewigkeit.

Tie with the rope of peace

Weak congregation,

Remove from our homeland

Persecution, melancholy, and danger.

Give us peace

To go through the journey

This short time,

Until you will take us,

To where we will sing

Blessed are you forever. 
Furthermore, in this stanza, the author still describes how the human condition is so weak and in need of God's help and peace which is expressed in lines 2 and 3. In line 3 there are dictions in the form of Verfolgung, Trübsal und Gefahr, this explains that at the time of making this poem The author is going through a difficult time. Accordingly, based on the author's biography in 1633 - 1636 the author was doing a noble task, namely spreading Christianity on European soil, but he had to do it secretly and also had to find a place to take refuge, due to the political affairs of the kingdom at that time. Then in the next line, namely 5-10, the author reveals that humans are getting tired and want to live a short or temporary life quietly and peacefully, until the time on earth is finished and ends in the real eternity, namely heaven, which is where humans are free from all troubles and only praise and glorify God forever.

Overall, the religious values that can be learned from this poem are that humans without the intervention of our Lord are just ordinary people who are afraid of darkness, mistakes, persecution, misfortune, and danger. But because of God's great love, we still get a new day every day in the world with a temporary time, therefore we should give thanks and respect for the glory of God and always rely on God in all things so that we may be in a place of eternity and praise God forever.

\section{Conclusions}

Based on the semiotic analysis of the poem Morgenlied by Martin Opitz, there is a sign system in the form of icons, indexes, and symbols. Signs that stand out in this Morgenlied poem are index marks and symbols, compared to iconic signs. These signs also reveal how the mercy and glory of God are described in verse 1 , while in verse 2 , they express a lot of darkness and fear or doubts about human actions and actions, and ask God for help to return to the right path. Likewise with verse 3, which contains the situation that the author is experiencing at that time and asks for calm or peace in living a short time remaining in the world, and hopes to be able to praise God forever in eternity. There are also religious values that can be learned from this poem, namely that humans without the intervention of God, humans are just ordinary people who are afraid of darkness, mistakes, persecution, misfortune, and danger. But because of God's great love, humans still get a new day every day in the world with a temporary time, therefore we should give thanks and respect for the glory of God and always rely on God in all things.

\section{References}

Adudu, H. H., \& Husain, D. (2019). Semiotic Analysis in William Blake Poems. British (Jurnal Bahasa dan Sastra Inggris), 8(1), 39-54.

Besbes, K. (2011). Rehabilitating Literary Theory: A Practical Guide for the Critical and Semiotic Analysis of Poetry and Drama. Universal-Publishers.

Carstens, R. (1991). Damshäuser, B., und KH Ramadhan [Hrsg.]: Malam Biru di Berlin-Blauer Abend in Berlin (Book Review). Orientalistische Literaturzeitung, 86(5), 577.

Cobley, P., Deely, J., Kull, K., \& Petrilli, S. (2011). Semiotics continues to astonish. Thomas A. Sebeok and the.

Chandler, D. (2007). Semiotics: the basics. Routledge.

Endaswara, Suwardi. (2011). Metodologi Penelitian Sastra. Yogyakarta: FBS Universitas Negeri Yogyakarta

Farras, P. (2020). A SEMIOTIC ANALYSIS ON ELDORADO POEM BY EGDAR ALLAN POE (Doctoral dissertation, Universitas Teknokrat Indonesia).

Galantucci, B., Garrod, S., \& Roberts, G. (2012). Experimental semiotics. Language and Linguistics Compass, 6(8), 477-493.

Hikmat Ade, Dkk. (2017). Kajian Puisi- Buku Bahan Ajar. Jakarta: $\quad$ UHAMKA $\quad$ FPBS IKIP Press.

Lendo, Sjuul Juliana. (2019). Bildungscharakterwerte Im Gedicht Die Schritte von Albrecht Goes Eine Struktural-Semiotische Analyse. Scientific Journal of German Language, Literature and CultureDAF Germanistik German Studies. No.4. Pp.93-97.

Manning, P. (2010). The semiotics of brand. Annual review of anthropology, 39, 33-49.

Pradopo, Rachmat Djoko. (2010). Pengkajian Puisi. Yogyakarta: UGM Press

Rokhmansyah, Alfian. (2014). Studi Dan Pengkajian Sastra. Yogyakarta: Graha Ilmu Sipahutar, R., \& Arianto, T. (2019). An analysis of semiotic Riffaterre in Walt Whitman selected Poem. Jurnal Basis, 6(2), 237-248.

Yelle, R. A. (2021). Semiotics. In The Routledge Handbook of Research Methods in the Study of Religion (pp. 434-444). Routledge. 